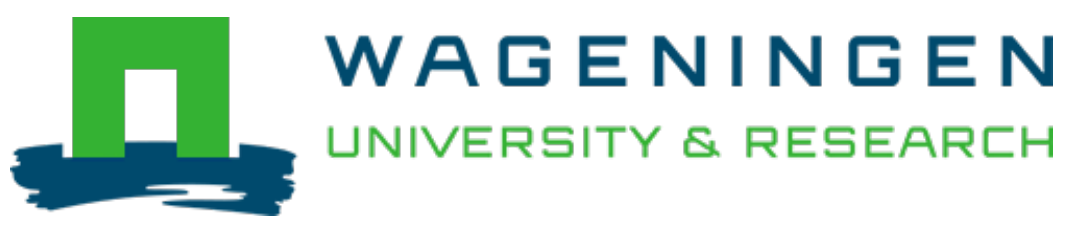

\title{
Nutrients, technological properties and genetic relationships among twenty cowpea landraces cultivated in West Africa
}

\author{
International Journal of Food Science and Technology \\ Madode, Y.E.E.; Linnemann, A.R.; Nout, M.J.R.; Vosman, B.J.; Hounhouigan, D.J. et al \\ https://doi.org/10.1111/j.1365-2621.2012.03146.x
}

This publication is made publicly available in the institutional repository of Wageningen University and Research, under the terms of article $25 \mathrm{fa}$ of the Dutch Copyright Act, also known as the Amendment Taverne. This has been done with explicit consent by the author.

Article 25 fa states that the author of a short scientific work funded either wholly or partially by Dutch public funds is entitled to make that work publicly available for no consideration following a reasonable period of time after the work was first published, provided that clear reference is made to the source of the first publication of the work.

This publication is distributed under The Association of Universities in the Netherlands (VSNU) 'Article $25 \mathrm{fa}$ implementation' project. In this project research outputs of researchers employed by Dutch Universities that comply with the legal requirements of Article $25 \mathrm{fa}$ of the Dutch Copyright Act are distributed online and free of cost or other barriers in institutional repositories. Research outputs are distributed six months after their first online publication in the original published version and with proper attribution to the source of the original publication.

You are permitted to download and use the publication for personal purposes. All rights remain with the author(s) and / or copyright owner(s) of this work. Any use of the publication or parts of it other than authorised under article $25 \mathrm{fa}$ of the Dutch Copyright act is prohibited. Wageningen University \& Research and the author(s) of this publication shall not be held responsible or liable for any damages resulting from your (re)use of this publication.

For questions regarding the public availability of this publication please contact openscience.library@wur.nl 


\title{
Original article \\ Nutrients, technological properties and genetic relationships among twenty cowpea landraces cultivated in West Africa
}

\author{
Yann E. Madodé, ${ }^{1,2,3}$ Anita R. Linnemann, ${ }^{2 *}$ Martinus J.R. Nout, ${ }^{3}$ Ben Vosman, ${ }^{4}$ Djidjoho J. Hounhouigan ${ }^{1}$ \& \\ Martinus A.J.S. van Boekel ${ }^{2}$ \\ 1 Faculté des Sciences Agronomiques, Université d’Abomey-Calavi, Abomey-Calavi, Bénin, 01 BP 526 Cotonou, Benin \\ 2 Product Design and Quality Management group, Wageningen University, P.O. Box 8129, 6700 EV Wageningen, The Netherlands \\ 3 Laboratory of Food Microbiology, Wageningen University, P.O. Box 8129, 6700 EV Wageningen, The Netherlands \\ 4 Wageningen UR Plant Breeding, Wageningen University and Research centre, P.O. Box 16, 6700AA Wageningen, The Netherlands
}

(Received 2 March 2012; Accepted in revised form 12 June 2012)

\begin{abstract}
Summary The genetic relationships among twenty phenotypically different cowpea landraces were unravelled regarding their suitability for preparing West African dishes. Amplified fragment length polymorphism classified unpigmented landraces (UPs) as highly similar (65\%, one cluster), contrary to pigmented landraces (PLs, three clusters). UPs contained, in $\mathrm{g} \mathrm{kg}^{-1}$ d.w., less fibre (24) and phenolics (3) than PLs (56 and 8, respectively) but had bigger seeds (200 g d.w. for 1000 seeds) and lower water absorption capacity at $30{ }^{\circ} \mathrm{C}$ (1049 $\mathrm{g} \mathrm{kg}^{-1}$ ) than PLs (139 and 1184, respectively). In $\mathrm{g} \mathrm{kg}^{-1}$ d.w., protein (255), ash (39), calcium (0.95), phytate $(9.3)$, iron (0.07) and zinc (0.04) contents were similar. UPs genetic similarities corroborated with their chemical composition and functionality clustered by principal component analysis. Therefore, UPs are well interchangeable regarding chemical composition and suitability for boiled and fried cowpea dishes in contrast to PLs. PLs have potential for innovative product design owing to their functional properties.
\end{abstract}

Keywords Chemical composition, DNA analysis, functional properties, legumes.

\section{Introduction}

A landrace is defined by Camacho et al. (2006) as 'a dynamic population of a cultivated plant species that has historical origin, distinct identity and lacks formal crop improvement, as well as often being genetically diverse, locally adapted and associated with the traditional farming systems'. Culinary and cultural preferences and secondary uses of the landraces (leaves for sauce, roots for infusions, etc.) are also associated with their preservation and cultivation (Almekinders et al., 1994). Consequently, farmers chiefly cultivate landraces, which have social and economic value for them (Kayode et al., 2006; Zannou et al., 2008).

In Africa, cowpea (Vigna unguiculata L. Walp) is considered a 'hunger-season crop' (Agbicodo, 2009). It is recognised as originating from Africa (Padulosi \& Ng, 1997; Timko \& Singh, 2008) although a debate is ongoing on the story of its domestication. $\mathrm{Ng} \&$

\footnotetext{
*Correspondent: Fax: + 31317483669 ;

e-mail: anita.linnemann@wur.nl
}

Marechal (1985) identified West Africa as the centre of diversity for cultivated cowpea. A wide range of cultivated cowpea landraces exists in different West African countries as judged on phenotype. Different molecular techniques such as simple sequence repeats molecular markers (SSRs) (Asare et al., 2010), amplified fragment length polymorphism (AFLP) (Fang et al., 2007) and random amplified polymorphic DNA markers (RAPD) (Ba et al., 2004; Zannou et al., 2008) demonstrated a low genetic diversity in cultivated cowpea. Pasquet (1999) showed that the diversity in cultivated cowpea is much lower than the genetic diversity in wild cowpea and postulated its single domestication event. This was confirmed by $\mathrm{Ba}$ et al. (2004). Nigeria (Vaillancourt \& Weeden, 1992) and North Eastern Africa (Coulibaly et al., 2002) have also been suggested as domestication centres for cowpea. Timko \& Singh (2008) suggested the probable domestication of cowpea by different ethnic groups or the contamination of the native gene pool by the cultivated cowpea.

The three most frequently consumed cowpea-based dishes in Benin are as follows: (i) Atassi (a mixture of 
boiled rice and whole cowpea) also called Waakye, (ii) Ata (deep-fat fried cowpea dumpling from decorticated ground beans), also named Akara or Koose and (iii) Abobo (boiled whole cowpea) (Madode et al., 2011). They are also consumed in other West African countries (Dovlo et al., 1976). The behaviour of cowpea during processing of these dishes depends on the content and properties of its proteins, starch, and fibres (Sathe, 2002; Granito et al., 2007). Moreover, properties such as fat absorption capacity (FAC) are referred to as critical for the profitability of Ata production as fat is an expensive commodity (Nout, 1996). Consequently, functional properties are relevant for food processors.

Oluwatosin $(1997,1999)$, who studied fifteen varieties of cowpea cultivated in Nigeria, concluded that genotype and environment notably affected their yield and/or physicochemical properties. Zannou et al. (2008) identified and genotyped, in Benin, 70 landraces but their nutritional and functional characteristics were not investigated. Nutritional information on such landraces is relevant for enhanced dietary diversification and food security programmes (Frison et al., 2006). Up till now, cowpea breeding has mainly focused on crop duration, yield, resistance to major diseases, insect attacks, parasitic weeds, tolerance to severe environmental stresses, protein content and cooking time (Singh et al., 1997). Recent studies pointed at the necessity to integrate the needs of the food chain actors (farmers, processors, traders and consumers) early in the procedure leading to the development of new varieties (Kitch et al., 1998; Quaye et al., 2011). The satisfaction of these actors can reconnect them to their productive resources, local market and locally processed and culturally accepted dishes. Such a reconnection was identified by Quaye et al. (2009) as an essential step towards food sovereignty.

Our study of cowpea landraces was undertaken to assess the relationship between genetics, chemical composition, divalent minerals and complexing compounds, and some functional properties of practical importance to predict the processing behaviour of cowpea landraces. The ultimate goal is to identify the landraces with the best nutritional and functional properties.

\section{Material and methods}

\section{Seed collection}

\section{Seed collection areas}

Twenty landraces were collected from farmers and markets in three agro-ecological zones of Benin in 2008, namely the Coastal Sandy Zone (CSZ), the Sudan-guinea Zone with Ferralitic soils (SZF) and the Transitional Sudan-guinea Zone (TSZ) (Dagbenonba- kin et al., 2003) (Fig. 1). CSZ and SZF are characterised by a subequatorial climate with four seasons, an annual rainfall of $900-1400 \mathrm{~mm}$ and a plant growth period of 240 days. The TSZ is an intermediate area between the Sudan-guinea zone with four seasons and the Sudan-zone with two seasons, which is characterised by $1200-1400 \mathrm{~mm}$ rainfall, and a plant growth period of 240 days.

\section{Seed multiplication}

After collection, seeds were multiplied in Zogbodomey $\left(7^{\circ} 4^{\prime} 60^{\prime \prime} \mathrm{N}-2^{\circ} 6^{\prime} 0^{\prime \prime} \mathrm{E}\right)$ within the SZF. Seeds were sown in plots at a spacing of $0.80 \mathrm{~m}$ between rows and $0.2 \mathrm{~m}$ within rows during the major rainy season (April-July 2009). The plots were not fertilised. Weeds were controlled manually by hoeing twice before the end of the season. At maturity, dried pods were harvested and threshed. Foreign material was removed and seeds were sundried until $10-15 \%$ moisture content. Dried seeds were stored in sealed plastic bags at $-25{ }^{\circ} \mathrm{C}$ prior to the laboratory investigations; the storage lasted for more than 6 months prior to the determination of functional properties.

\section{DNA extraction and AFLP analysis}

Cowpea seeds were grown in small pots in a greenhouse of the Wageningen UR Plant Breeding group, Wageningen University, till about four leaves' stage. Two samples of $1 \mathrm{~cm}^{2}$ leaf material each were harvested from fresh and young leaflets of each landrace. DNA was extracted with the KingFisher (Thermo Fisher Scientific Oy, Vantaa, Finland) using the Agowa Sbeadex Maxi Plant kit according to the manufacturer's protocol (Agowa genomics, Berlin, Germany). The DNA concentration was measured using the Nanodrop (NanoDrop Technologies, Inc., Wilmington, DE, USA).

Landraces were fingerprinted by AFLP, essentially as described by Vos et al. (1995). About $250 \mathrm{ng}$ DNA was used for a one-step restriction/ligation reaction (Arens et al., 1998). DNA was digested with EcoRI and MseI. Preamplification was with nonselective primers E01 and M02. Selective amplification was performed with the E44M59, E39M59, E39M60 and E33M60 primers, which were labelled with the 700_dye, while E33M59, E35M59, E35M50, E32M59 and E32M62 primers were labelled with the 800_dye. The polymerised chain reaction (PCR) products were separated on a $6.5 \%$ polyacrylamide gel on a Licor 4200 Global system. About 228 markers were identified. Bands were scored as present (1) or absent (0) for each marker using the Quantar software (Keygene, the Netherlands) and transferred into a binary data matrix. 


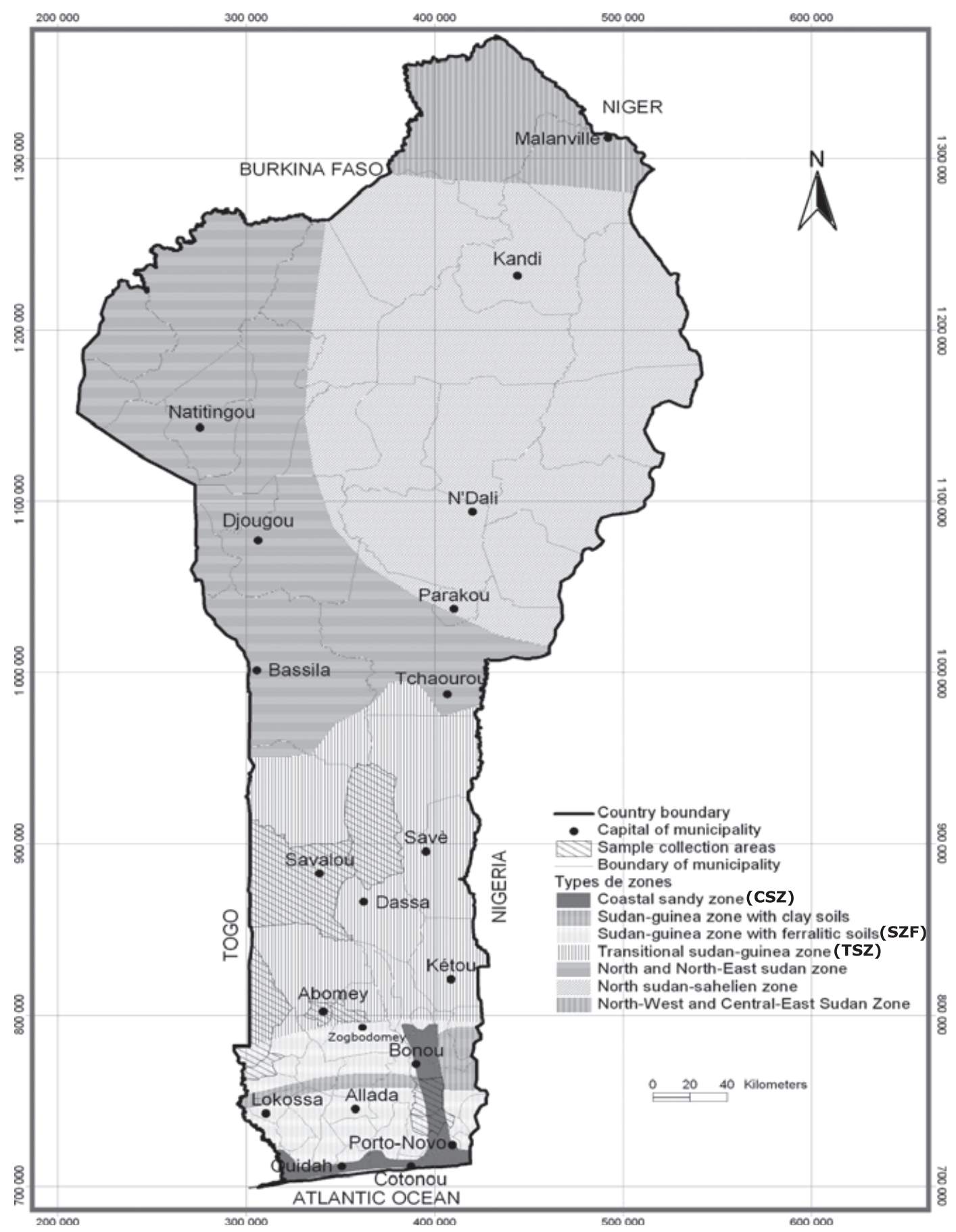

Figure 1 Map of Benin indicating municipalities of landrace collection.

\section{Crude fat, crude protein, ash and crude fibre}

Seeds were milled to flours in a Retsch mill fitted with a $0.5 \mathrm{~mm}$ sieve. AOAC methods 27.006, 7.070 and 14.006 (AOAC, 1984) were used to determine their crude fat, crude fibre and ash content, respectively.
Crude protein content $(\mathrm{N} \times 6.25)$ was determined from nitrogen content quantified with Dumas method (Jung et al., 2003) by using a Flash EA $1112 \mathrm{~N}$ analyser (Thermo Electron Corporation, Delft, the Netherlands) and D-methionine (Acros organics, Geel, Belgium) as nitrogen calibration standard. 


\section{Iron, zinc and calcium}

Cowpea flours were digested using a mixture of hydrofluoric acid and concentrated nitric acid $\left(\mathrm{HNO}_{3}-\right.$ $\mathrm{HF}-\mathrm{H}_{2} \mathrm{O}_{2}$ ). An inductively coupled plasma optical emission spectrometer (ICP-OES) (Elan 6000, PerkinElmer, Norwalk, CT, USA) was used to determine iron, zinc and calcium content of the digested cowpea flours (Temminghof, 1997).

\section{Mineral complexing compounds}

Phytate content (IP6) was assessed in duplicate according to Bentsink et al. (2003) using an IonPac AG11HC guard column and a Dionex IonPac AS11-HC analytic column. Eluent and elution were set as follows: $0-15 \mathrm{~min}, 25-100 \mathrm{~mm} \mathrm{NaOH} ; 15-20 \mathrm{~min}$, $500 \mathrm{~mm} \mathrm{NaOH}$ to rinse the column; 20-35 min, $25 \mathrm{~mm} \mathrm{NaOH}$ to equilibrate the column.

Total phenolic compounds (TPC) were extracted in duplicate with $\mathrm{HCl} /$ methanol $(1: 100)$ and subsequently measured by the method described by Singleton \& Rossi (1965) which was modified as follows: $5 \mathrm{~mL}$ of water, $1 \mathrm{~mL}$ of extract, $1 \mathrm{~mL}$ of Folin-Ciocalteu's phenol reagent (Merck, Darmstadt, Germany) and $1 \mathrm{~mL}$ of saturated sodium carbonate solution were mixed. Then, the volume of the solution was adjusted to $25 \mathrm{~mL}$ with Millipore water $(0.22 \mu \mathrm{m})$ and the mixture was incubated for $15 \mathrm{~min}$. Absorbance was measured at $725 \mathrm{~nm}$. Freshly prepared blanks and standard (Tannic acid, EC 215753-2, Sigma Aldrich, Steinheim, Germany) were analysed according to the same procedure.

\section{Seed weight}

Thousand seed weight $(1000 \mathrm{Sw})$ was determined in triplicate as described by Kayode et al. (2006).

\section{Functional properties}

Water and fat absorption capacities (WAC and FAC) were determined as described by Ghavidel \& Prakash (2006) and expressed in $\mathrm{g}$ of water or oil absorbed per $\mathrm{kg}$ of cowpea flour dry weight (d.w.)

To determine foaming capacity and stability (FC and FS), $2 \mathrm{~g}$ of cowpea flour was mixed with $100 \mathrm{~mL}$ of distilled water and blended for 6 min with an Ultra-Turrax emulsifier at $12000 \mathrm{rpm}$ at ambient temperature $\left(28-30{ }^{\circ} \mathrm{C}\right)$. The contents were immediately transferred quantitatively to a $250 \mathrm{~mL}$ measuring cylinder and the volume of the foam recorded. Foaming capacity was expressed as the percentage of volume increase against the initial volume of the suspension. Foam stability was determined by monitoring the fall in the foam volume as a function of time for $120 \mathrm{~min}$ at $28-30{ }^{\circ} \mathrm{C}$ and was expressed as the foam stability at $120 \min (\mathrm{FS} 120)$.

\section{Survey of cowpea processors}

Beninese food processors from two cowpea production areas (Savalou and Abomey) and two areas where cowpea is not produced (Porto-Novo and Cotonou) were interviewed to assess their perception of the required quality of raw materials for Atassi production. Sample size was set according to Dagnelie (1998). In each community, the proportion of Atassi processors was assessed through a random check on 175 people, selected at the main market of the locality, during a market day. Atassi processors identified that day helped to find the other processors active in the region. In total, fifty two Atassi processors (twenty two in production areas and thirty outside production areas) were identified in the neighbourhood of the main market of these localities.

\section{Data analysis}

A similarity matrix was generated on the basis of AFLP band scorings using the Jaccard similarity coefficient (JSC) to determine genetic diversity (Digby \& Kempton, 1987). A dendrogram was obtained using the unweighted pair group method of arithmetic mean (UPGMA) algorithm implemented in the NTSYS package (version 2.1) (Rohlf, 2000).

The statistical package IBM-SPSS 19.00 was used to process the data on the properties of the landraces. The characteristics of the clusters were compared using the Multivariate ANOVA followed by the Student Newman and Keuls post hoc test. Physicochemical and technological properties of cowpea landraces were subjected to a principal component analysis to cluster these landraces on the basis of the parameters that best characterise them. Five properties (seed weight, TPC, fibre, phytate and WAC) were considered to run the PCA as the determinant of the correlation matrix obtained from these properties $(0.046)$ was greater than 0.00001 as recommended by Field (2006). Moreover, the Kaiser -Meyer-Olkin measure of sampling adequacy (0.7) is higher than the threshold of 0.5 recommended by Field (2006). Kaiser criterion of retaining components with eigenvalues greater than 1 and the average communalities value (greater than 0.6) were used to determine the number of components. The PCA was followed by an oblimin (oblique) rotation as the variables appeared to be correlated. The groups obtained from this data reduction analysis were compared with the clusters obtained from the genetic analysis. 


\section{Results and discussion}

Genetic discrimination of cowpea landraces and relation with the collection areas

The dendrogram depicted in Fig. 2 shows two main clusters, namely $\mathrm{C} 1$ and $\mathrm{C} 2$ with two subclusters each: $\mathrm{C} 11, \mathrm{C} 12$ and $\mathrm{C} 21, \mathrm{C} 22$. These subclusters contain eight, five, four and three landraces, respectively (Table 1). All the unpigmented landraces in our collection are in cluster C12.

The two major clusters in the dendrogram suggest that the cultivated cowpea landraces collected in Benin probably have two different origins. Wild cowpeas may have been domesticated by different socio-cultural groups (Timko \& Singh, 2008) following multiple selections according to the production environments and the needs of their users.

The Jaccard genetic similarity coefficient was equal or higher than $85 \%$ for three pairs of landraces: Teivigboto and Sokan (99\%), Kpeikoun and Sewekoun $(88 \%)$, Atchawe-tola and Aiglo (85\%). Teivigboto and Sokan, collected in Dangbo and Adjohoun, both located in the CSZ, have the same seed colour, testa texture and $1000 \mathrm{Sw}$. It is likely that these landraces are identical as the $1 \%$ dissimilarity (one band difference) shown may result from experimental errors (Jones et al., 1997; Vosman et al., 2004). Sewekoun and Kpeikoun, from the Abomey region in TSZ, were indicated by farmers as different but have the same seed colour and testa texture. Atchawe and Aiglo, which were collected in CSZ and TSZ, respectively, are morphologically rather similar. Landraces of these pairs may share common ancestry.

\section{Nutritional composition of cowpea landraces}

The protein, fat, ash and fibre contents $\left(\mathrm{g} \mathrm{kg}^{-1} \mathrm{~d} . \mathrm{w}\right.$.) range from 218 to 299,11 to 27,32 to 43 , and 18 to 69 , respectively (Table 2 ) and are in the same range as reported by Longe (1980) for varieties obtained from different origins, and grown at a Nigerian research centre, namely $280 \pm 45 ; 19 \pm 3 ; 38 \pm 8,31 \pm 6$, respectively. Pigmented landraces (C11, C21, C22: $58 \mathrm{~g} \mathrm{~kg}^{-1}$ d.w.) contained more than twice as much fibre as unpigmented landraces (C12: $24 \mathrm{~g} \mathrm{~kg}^{-1} \mathrm{~d} . \mathrm{w}$.) (Table 3). These observations are in line with those made by Morrison et al. (1995) who demonstrated that the amount of lignin, a major component of fibre, in pigmented cowpea seed coats was twice the amount found in unpigmented ones. In pulses, tannin content also contributes to seed coat colour and pigment distribution or intensity (Caldas \& Blair, 2009) and tannins are positively correlated to fibre (Patane, 2006). As fibres are known to be mainly located in the seed coats, seeds with thin coats like unpigmented cowpea are expected to contain less fibre than thicker coated seeds like pigmented cowpeas. In this study (data not presented), we found that when beans are soaked, manually dehulled and dried, the dried seed coat portion represents 4 and $11 \%$ of the weight of the whole white (unpigmented) and brown (pigmented) beans, respectively.

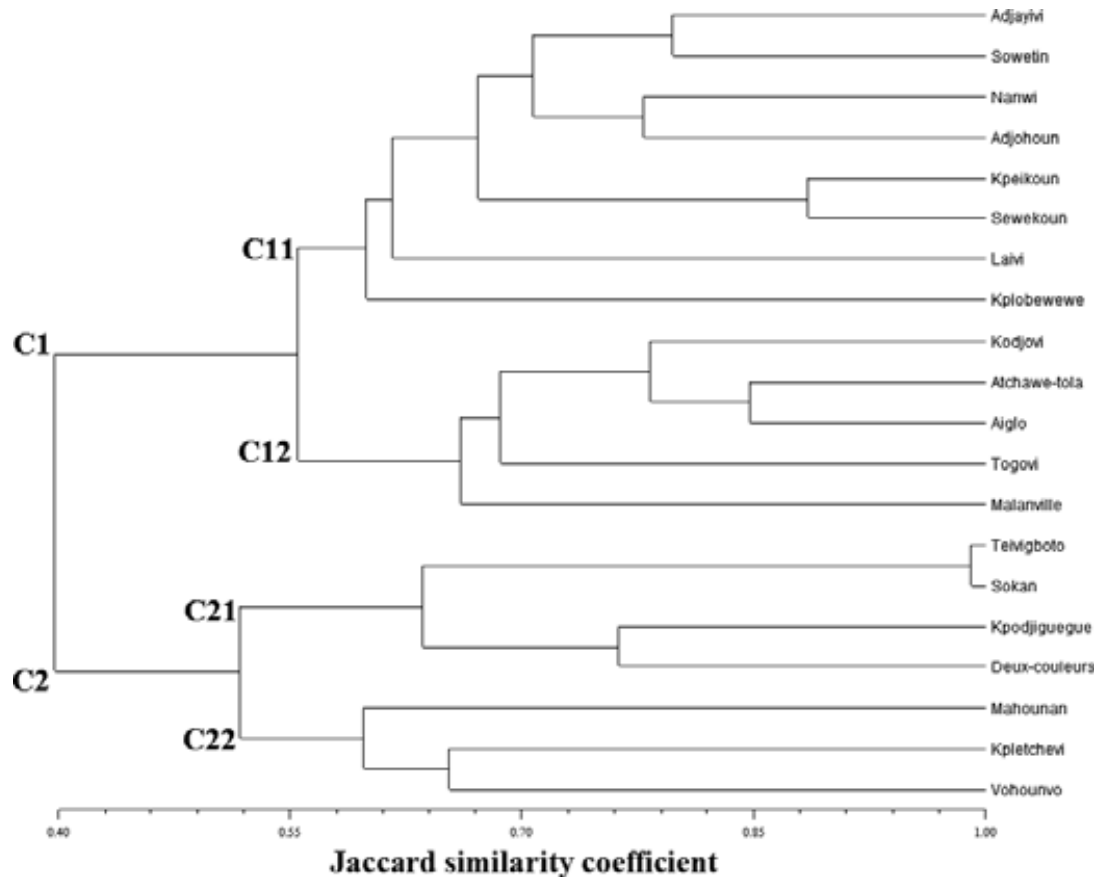

Figure 2 Dendrogram of the genetic relationship among cowpea landraces collected in Benin. 
Calcium content varied largely among landraces, namely from 0.7 to $1.4 \mathrm{~g} \mathrm{~kg}^{-1}$ d.w. The landraces Laivi and Sowetin showed the highest content, 1.4 and $1.2 \mathrm{~g} \mathrm{~kg}^{-1}$ d.w., respectively. Cowpea landraces contained far less iron (56-104 $\mathrm{mg} \mathrm{kg}^{-1}$ d.w.; Teivigboto and Sokan, respectively) and zinc (37-54 $\mathrm{mg} \mathrm{kg}^{-1}$ d.w.; Sokan and Sewekoun, respectively) than calcium. Chinma et al. (2008) found higher calcium contents (4.2$5.8 \mathrm{~g} \mathrm{~kg}^{-1}$ d.w.) and lower iron contents $(40-48 \mathrm{mg}$ $\mathrm{kg}^{-1}$ ) in cowpea varieties cultivated in Nigeria compared to landraces grown in Benin in our study. Oluwatosin (1998) reported similar iron $\left(10-120 \mathrm{mg} \mathrm{kg}^{-1}\right.$ d.w.) and zinc contents (30-80 $\mathrm{mg} \mathrm{kg}^{-1}$ d.w.) in cowpea landraces commonly used in Nigeria while calcium content was very high (2.5-7.1 $\mathrm{mg} \mathrm{kg}^{-1}$ d.w.). Such differences between studies could be attributed to varietal differences but are more likely to result from differences in soil fertility. Oluwatosin (1998) demonstrated that the growing conditions affect the mineral content of the harvested cowpea seeds.

Two antinutrients, namely phenolics and phytate, are known to form complexes with divalent minerals such as calcium, iron and zinc. The contents of these antinutrients are variable from one landrace to the other (Table 2). No statistically significant difference $(P<0.05)$ was observed between the different genetic clusters neither between pigmented and unpigmented landraces (Table 3). Furthermore, TPC occurred in significantly lower amounts $(P<0.05)$ in unpigmented landraces $\left(3.0 \mathrm{~g} \mathrm{~kg}^{-1}\right.$ d.w. $)$ than in pigmented ones $\left(8.0 \mathrm{~g} \mathrm{~kg}^{-1}\right.$ d.w.). Among pigmented landraces, TPC of genetic clusters $\mathrm{C} 11$ and $\mathrm{C} 22$ differ from $\mathrm{C} 21$. Therefore, although the pigmented landraces are not all alike, they concentrate more TPC than unpigmented ones. Kachare et al. (1988) observed the same pattern for Indian cowpea varieties. They proved that the difference in TPC content between unpigmented and pigmented landraces arose from the substantial quantity of phenolics in the seed coats of pigmented landraces; about $50 \%$ of TPC of pigmented landraces comes from seed coats against less that $20 \%$ for unpigmented landraces.

\section{Functional properties}

Characteristics of whole cowpea flour and cowpea seeds are presented in Tables 2 and 3. On average, pigmented landraces revealed a better ability to absorb water at room temperature $\left(1458 \mathrm{~g} \mathrm{~kg}^{-1}\right.$ d.w.) than unpigmented landraces $\left(1259 \mathrm{~g} \mathrm{~kg}^{-1}\right.$ d.w.). Fat absorption capacity at room temperature was similar $\left(928 \pm 62 \mathrm{~g} \mathrm{~kg}^{-1}\right.$ d.w.) for pigmented and unpigmented landraces $\left(944 \pm 63 \mathrm{~g} \mathrm{~kg}^{-1}\right.$ d.w.). The foaming capacity was similar for the different landraces and clusters. After $2 \mathrm{~h}$ at room temperature, the foam produced from cowpea flours was disaggregated. The remaining foam represented $18-22 \%$ of the initial volumes. High variability of foam stability among landraces was observed. Aiglo, Sowetin and Deux couleurs showed very low foam stability (Table 2).

Table 1 Genetic clustering and physical characteristics of collected cowpea landraces

\begin{tabular}{|c|c|c|c|c|c|}
\hline \multirow[b]{2}{*}{ Cluster (C) } & \multirow[b]{2}{*}{ Landraces (local names) } & \multirow[b]{2}{*}{ Agro-ecological origin } & \multicolumn{3}{|c|}{ Seeds physical characteristics } \\
\hline & & & Testa texture & Colour & 1000Sw (g d.w.) \\
\hline \multirow[t]{8}{*}{ C11 } & Adjawan & $\mathrm{CSZ}$ & Smooth & Streaked brown & 200.0 \\
\hline & Sowetin & $\operatorname{csz}$ & Smooth & Streaked light brown & 116.7 \\
\hline & Nanwi & $\mathrm{CSZ}$ & Smooth & Pure black & 105.7 \\
\hline & Adjohoun & $\mathrm{CSZ}$ & Smooth & Brown & 165.2 \\
\hline & Kpeikoun & FSZ & Smooth & Maroon & 107.1 \\
\hline & Sewekoun & FSZ & Smooth & Maroon & 131.3 \\
\hline & Kplobe wewe & FSZ & Smooth & Light Brown & 110.8 \\
\hline & Laivi & TSZ & Smooth & Creamy & 92.6 \\
\hline \multirow[t]{5}{*}{ C12 } & Atchawe-tola & $\mathrm{csz}$ & Wrinkled & Unpigmented & 222.9 \\
\hline & Kodjovi & TSZ & Wrinkled & Unpigmented \& black spots at bottom & 214.9 \\
\hline & Aiglo & TSZ & Wrinkled & Unpigmented & 177.7 \\
\hline & Togovi & TSZ & Wrinkled & Unpigmented & 167.1 \\
\hline & Malanville gros grains & TSZ & Wrinkled & Unpigmented & 215.3 \\
\hline \multirow[t]{4}{*}{$\mathrm{C} 21$} & Teivigboto & $\operatorname{csz}$ & Smooth & Maroon & 128.6 \\
\hline & Sokan & $\operatorname{csz}$ & Smooth & Maroon & 124.3 \\
\hline & Kpodjiguegue & $\mathrm{csz}$ & Smooth & Green grey & 112.7 \\
\hline & Deux couleurs & $\mathrm{csZ}$ & Smooth & Light brown and Brown & 124.9 \\
\hline \multirow[t]{3}{*}{$\mathrm{C} 22$} & Mahounan & TSZ & Smooth & Brown & 167.5 \\
\hline & Kpletchevi & TSZ & Smooth & Brown & 148.8 \\
\hline & Vohounvo & $\mathrm{CSZ}$ & Smooth & Brown & 144.4 \\
\hline
\end{tabular}

CSZ, costal and sandy zone; FSZ, ferralitic soil zone; TSZ, transitional Sudan-guinea zone; 1000Sw, thousand seed dry weight. 
Kerr et al. (2000) reported about $1560 \mathrm{~g}$ of water and $520 \mathrm{~g}$ of oil absorbed per $\mathrm{kg}$ of cowpea flour d.w. (milled through a $1.0 \mathrm{~mm}$ screen). Differences in hardness of seeds from different landraces and particle size distribution of the flours explain the variability in water and oil absorption capacities of our landraces as compared with others (McWatters, 1983; Kerr et al., 2000). The crude fibre content and WAC, in this study, were highly correlated $(r=0.66$, $P<0.01)$, confirming that fibre also affects the hydration properties of the flour (Granito et al., 2007).

As reported previously (Madode et al., 2011), many cowpea dishes are either fried or deep-fat fried in cooking oils and their storage is problematic. One of the most consumed cowpea dishes is Ata. High FAC values have been explained by the high prevalence of nonpolar amino acids in the flour (Abu et al., 2006) or the high moisture content in the batter prepared for frying (Patterson et al., 2004). Therefore, if the ideal moisture content in Ata production paste is identified, both pigmented and unpigmented landraces could be used to generate low fat containing dumplings. A low fat content is desirable from nutritional and health point of view to prevent obesity (Patterson et al., 2004).
FC values (42.5-44.9\%) measured in this research are comparable with those $(40 \%)$ reported by as Ghavidel \& Prakash (2006). The foaming capacity of the landraces showed no relation with the genetic clusters.

Thousand seed weight $(1000 \mathrm{Sw})$ varied significantly among landraces (Table 2); the pigmented landraces in our study were smaller $(132 \pm 28 \mathrm{~g}$ d.w. $)$ than the unpigmented ones. A significant Pearson correlation $(r)$ was found between $1000 \mathrm{Sw}$ and fibre $(r=-0.762)$, TPC $(r=-0.574)$ and WAC $(r=-0.621)$ at significance level of $1 \%$. When WAC was taken into account, our results differ with the ones observed by several authors (Williams et al., 1983; Avola et al., 2009) where a positive correlation between seed weight, water hydration capacity and hydration index was reported for chickpea and faba beans in whole seeds. This discrepancy can be explained by the fact that we measured it on flour instead of entire seed. This could be related to the barrier function of the seeds coat (Hung et al., 1993). In addition, seeds with high WAC had also high fibre content.

\section{Suitability of landraces for cowpea food production}

According to Patterson et al. (2004) FC, particle size of cowpea batter, and hydration properties are

Table 2 Chemical composition and functional attributes of cowpea landraces

\begin{tabular}{|c|c|c|c|c|c|c|c|c|c|c|c|c|c|c|}
\hline $\begin{array}{l}\text { Genetic } \\
\text { clusters (C) }\end{array}$ & Landrace & $\begin{array}{l}\text { Crude protein } \\
\text { (g kg } \mathbf{~ k}^{-1} \text { d.w.) }\end{array}$ & $\begin{array}{l}\text { Crude } \\
\text { fat }\end{array}$ & Ash & Fibre & $\begin{array}{l}\mathrm{Ca} \\
\text { (mg kg }^{-1}\end{array}$ & $\begin{array}{l}\text { Fe } \\
\text { d.w.) }\end{array}$ & $\mathrm{Zn}$ & $\begin{array}{l}\text { IP6 } \\
\operatorname{lg~kg}^{-1}\end{array}$ & $\begin{array}{l}\text { TPC } \\
\text { d.w.) }\end{array}$ & WAC & FAC & $\begin{array}{l}\text { FC } \\
(\%)\end{array}$ & FS120 \\
\hline \multirow[t]{8}{*}{ C11 } & Adjawan & 291.8 & 13.0 & 40.9 & 61.3 & 888.6 & 63.4 & 42.1 & 8.6 & 8.1 & 1414.7 & 999.5 & 43.0 & 24.0 \\
\hline & Sowetin & 262.5 & 22.2 & 43.2 & 55.7 & 1220.8 & 66.7 & 49.9 & 9.8 & 8.3 & 1568.9 & 867.7 & 42.0 & 7.0 \\
\hline & Nanwi & 267.5 & 17.2 & 36.7 & 60.1 & 1157.8 & 70.7 & 44.1 & 6.8 & 10.5 & 1569.7 & 1058.4 & 41.0 & 28.0 \\
\hline & Adjohoun & 268.2 & 26.9 & 39.6 & 46.3 & 891.2 & 64.7 & 50.0 & 7.8 & 9.1 & 1501.4 & 945.1 & 62.0 & 20.0 \\
\hline & Kpeikoun & 298.7 & 16.5 & 36.2 & 57.2 & 798.0 & 67.0 & 46.8 & 7.5 & 8.9 & 1424.9 & 906.1 & 44.0 & 23.0 \\
\hline & Sewekoun & 283.6 & 11.3 & 38.6 & 55.8 & 884.8 & 69.8 & 54.1 & 10.0 & 7.0 & 1496.9 & 820.4 & 44.0 & 14.0 \\
\hline & Kplobe wewe & 249.9 & 16.3 & 40.9 & 63.0 & 1006.5 & 69.4 & 52.2 & 8.8 & 4.6 & 1533.1 & 844.8 & 42.0 & 21.0 \\
\hline & Laivi & 224.2 & 10.9 & 42.6 & 68.8 & 1444.5 & 60.1 & 41.2 & 15.2 & 4.3 & 1356.5 & 891.1 & 47.0 & 29.0 \\
\hline \multirow[t]{5}{*}{$\mathrm{C} 12$} & Atchawe-tola & 244.0 & 13.8 & 37.1 & 24.5 & 1104.8 & 64.2 & 46.5 & 13.1 & 2.9 & 1181.4 & 943.3 & 45.0 & 19.0 \\
\hline & Kodjovi & 262.9 & 15.3 & 31.8 & 27.1 & 880.7 & 62.8 & 39.7 & 7.0 & 3.4 & 1212.3 & 866.6 & 46.5 & 33.0 \\
\hline & Aiglo & 263.0 & 17.6 & 36.5 & 25.8 & 1104.0 & 76.3 & 44.3 & 8.9 & 2.9 & 1312.5 & 971.9 & 42.0 & 4.0 \\
\hline & Togovi & 239.8 & 16.0 & 37.1 & 17.8 & 987.4 & 75.8 & 41.8 & 9.9 & 3.6 & 1237.7 & 1039.3 & 42.0 & 37.0 \\
\hline & $\begin{array}{l}\text { Malanville } \\
\text { gros grains }\end{array}$ & 218.4 & 14.1 & 36.9 & 25.8 & 883.0 & 57.5 & 39.8 & 9.9 & 2.5 & 1343.8 & 900.7 & 37.0 & 14.0 \\
\hline \multirow[t]{4}{*}{ C21 } & Teivigboto & 228.0 & 14.7 & 38.2 & 59.8 & 1001.2 & 55.7 & 40.0 & 10.2 & 6.7 & 1510.8 & 913.6 & 46.0 & 13.0 \\
\hline & Sokan & 241.5 & 16.6 & 35.9 & 59.5 & 1030.3 & 104.3 & 36.7 & 6.7 & 8.3 & 1438.6 & 1007.1 & 44.0 & 27.0 \\
\hline & Kpodjiguegue & 242.8 & 14.8 & 40.3 & 54.0 & 1114.4 & 59.2 & 45.8 & 8.4 & 10.8 & 1355.5 & 927.3 & 44.0 & 28.0 \\
\hline & Deux couleurs & 257.2 & 16.9 & 36.9 & 60.4 & 689.7 & 73.7 & 48.1 & 6.8 & 11.7 & 1520.8 & 926.7 & 38.0 & 5.0 \\
\hline \multirow[t]{5}{*}{$\mathrm{C} 22$} & Mahounan & 259.7 & 14.7 & 41.5 & 48.3 & 661.6 & 57.4 & 39.8 & 8.5 & 5.9 & 1402.4 & 913.3 & 46.0 & 11.0 \\
\hline & Kpletchevi & 243.4 & 14.4 & 40.7 & 56.0 & 998.5 & 58.9 & 42.0 & 11.9 & 7.2 & 1335.5 & 913.0 & 45.0 & 24.0 \\
\hline & Vohounvo & 273.6 & 14.3 & 41.9 & 56.5 & 893.3 & 60.4 & 40.2 & 11.0 & 8.4 & 1446.5 & 974.9 & 39.0 & 17.0 \\
\hline & Maximum & 298.7 & 26.9 & 43.2 & 68.8 & 1444.5 & 104.3 & 54.1 & 15.2 & 11.7 & 1569.7 & 820.4 & 37.0 & 4.0 \\
\hline & Minimum & 218.4 & 10.9 & 31.8 & 17.8 & 661.6 & 55.7 & 36.7 & 6.7 & 2.5 & 1181.4 & 1058.4 & 62.0 & 37.0 \\
\hline
\end{tabular}

TPC, total phenolic compounds; WAC, water absorption capacity; FAC, fat absorption capacity; FC, foaming capacity; FS120, foam stability after $120 \mathrm{mn} ; 1000 \mathrm{Sw}, 1000$ seeds dry weight. 


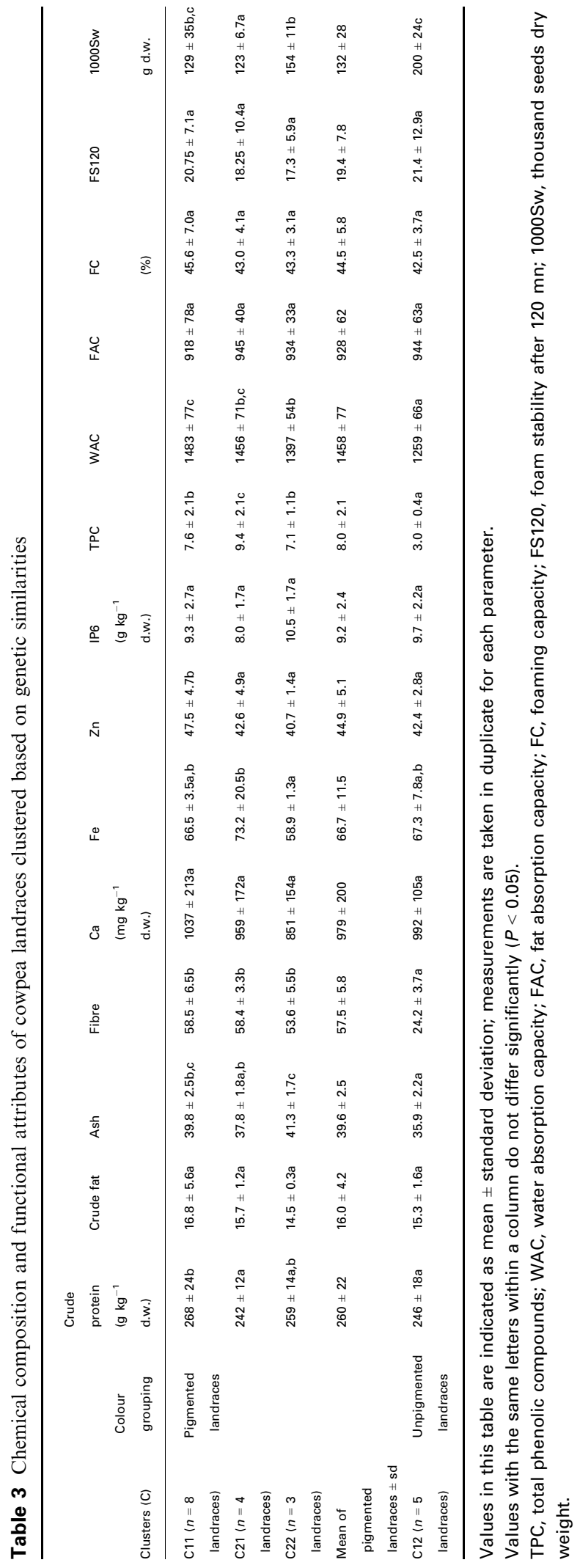

important for processing cowpea into Ata. Moreover, Nout (1996) demonstrated that FAC influences the final fat content of the dumpling. All landraces showed a FC of $42-45 \%$, except Adjohoun (a pigmented landrace), which has the highest foamability values $(62 \%)$. The latter landrace also has a high WAC, in the same range as Sewekoun, Teivigboto, Deux couleurs, Kplobewewe and Sowetin. Although no significant difference was found for FAC, Sowetin has one of the lowest FAC as well as Kplobewewe and Sewekoun. As reported by processors, pigmented landraces are often not used for Ata processing owing to the thickness of their seed coat that necessitates tedious manual dehulling as compared to unpigmented ones. The pigmented seed coats and black eyes in the whole pigmented cowpea flours darken the batter and the interior of the resulting Ata, diminishing its acceptability by West African consumers, who prefer Ata with a light-coloured crumb (Patterson et al., 2004); dehulling of pigmented seeds could make them attractive for Ata making. The hydration and foaming properties of the cotyledons from different landraces should be evaluated for Ata processing.

Interviewed Atassi processors (Table 4) revealed that a brown seed colour ( $41 \%$ of respondents) and integrity of the beans (indicating the absence or low incidence of weevil infestation in cowpea seeds, $50 \%$ of respondents) were 'very important' quality criteria of cowpea intended for Atassi production. In addition, cookability and high swelling ability were considered 'moderately important' (54 and 52\% of respondents). The WAC of the beans is a good indicator of these criteria selected as 'moderately important' by the processors. White and brown cowpeas are the two types of cowpea available to consumers in most markets, especially in urban areas in Benin and in other countries of West Africa (Fang et al., 2007). In general, cowpea processors did not emphasise cowpea seed size as a major quality criteria for Atassi processing; $62 \%$ of the processors considered it to be irrelevant. All the compositional and functional properties of the unpigmented and pigmented landraces in our study were similar, except for WAC, $1000 \mathrm{Sw}, \mathrm{TPC}$ and fibre contents (Table 3). The brown landraces collected in this study were Adjawan, Adjohoun, Sowetin, Kplobewewe, Deux couleurs, Mahounan, Kpletchevi, and Vohounvo. Of these, Adjohoun, Deux couleurs, Kplobewewe and Sowetin have the best WAC. These landraces could be recommended for Atassi (and Abobo) processing to those who prefer brown-seeded cowpeas for Atassi (53\% of processors; Table 4).

\section{Clustering on the basis of functionality}

In Fig. 3a, we positioned the twenty landraces as a function of two principal components. Only the 
two-first components displayed eigenvalues higher than 1 (according with the Kaiser criterion), and the scree plot suggested two meaningful components before the inflexion of the plot. Together and after rotation, these two components accounted for $85.3 \%$ of the total variance in the initial data.

Table 4 Importance of cowpea quality criteria for Atassi processors

\begin{tabular}{llccr}
\hline Quality criteria & Modalities & Very & Moderate & Not \\
\hline Cowpea colour & Brown & 14 & 13 & 5 \\
& Unpigmented & 6 & 5 & 4 \\
& Any & 0 & 0 & 2 \\
Cleanness & Total (49) & $20^{*}$ & 18 & 11 \\
& Absent & 0 & 0 & 0 \\
& Few & 24 & 18 & 0 \\
Cookability & Irrelevant & 3 & 3 & 4 \\
& Total (52) & 27 & 21 & 4 \\
& Fast & 2 & 7 & 4 \\
Swelling ability & Medium & 1 & 13 & 10 \\
& Slow & 0 & 0 & 0 \\
& Total (37) & 3 & 20 & 14 \\
& High & 5 & 23 & 10 \\
& Low & 0 & 0 & 5 \\
Seed size & Irrelevant & 0 & 0 & 1 \\
& Total (44) & 5 & 23 & 16 \\
& Small & 0 & 1 & 6 \\
& Medium & 3 & 8 & 10 \\
& Big & 4 & 2 & 4 \\
& Irrelevant & 0 & 0 & 9 \\
& Total (47) & 7 & 11 & 29 \\
\hline
\end{tabular}

* Number of respondents that allocated a certain importance to a defined quality criteria.

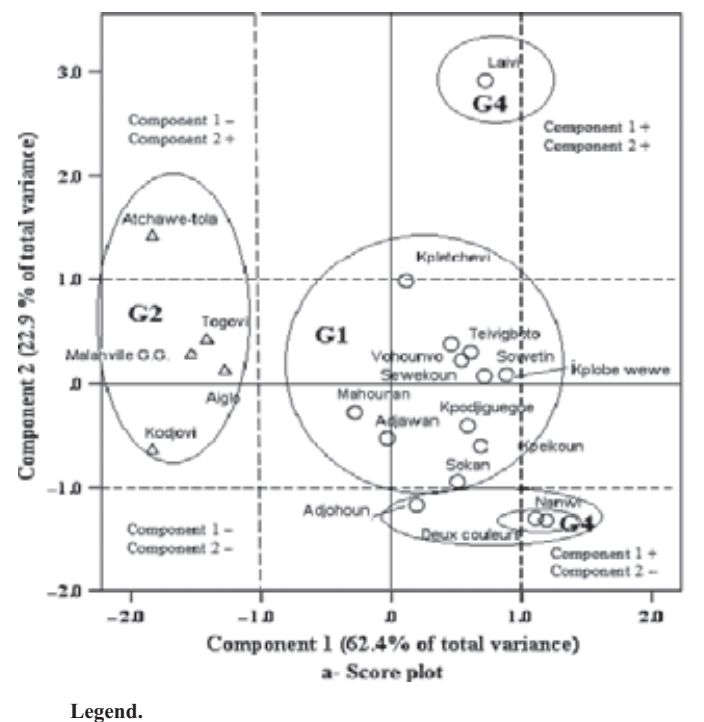

$\circ=$ Unpigmented landraces $($ Group G2)
Communalities after extraction and component loadings after rotation are presented in Table 5. Communalities were all greater than 0.6. Therefore, enough variance of the initial variables has been extracted from the selected components. In interpreting the rotated component pattern, we considered a parameter as a good contributor to the variation in the dataset when its component loading is greater than 0.6. Therefore, WAC, phenolic and fibre contents contribute positively to component 1 whereas seed weight $(1000 \mathrm{Sw})$ related negatively with this component (Fig. 3b). Phytate content characterised component 2.

An arbitrary threshold of one is assumed to discuss distribution of landraces in the score plot (Fig. 3a) as a solution to the implemented data reduction. Consequently, landraces with an absolute coordinate greater than one are considered well represented on the targeted component. Moreover, all landraces located near the origin within $\mathrm{a} \pm 1$ area are considered not significantly represented on the component. Group 1 (Kpletchevi, Teivigboto, Vohounvo, Sowetin, Kplobewewe, Mahounan, Kpodjiguegue, Adjawan, Kpeikoun, Sokan) showed a low correlation with component 1 and component 2. Group 2 (Atchawe-tola, Togovi, Malanville gros grains, Aiglo and Kodjovi) and group 3 (Nanwi and Deux couleurs) showed respectively negative and positive correlations with component 1 . Group 4 as well as Atchawe-tola showed a high positive correlation with component 2. In contrast, Adjohoun, Nanwi and Deux couleurs negatively correlated with component 2 .

From this description, landraces of group 1 possess no particular trait to clearly differentiate them (Fig. 3).

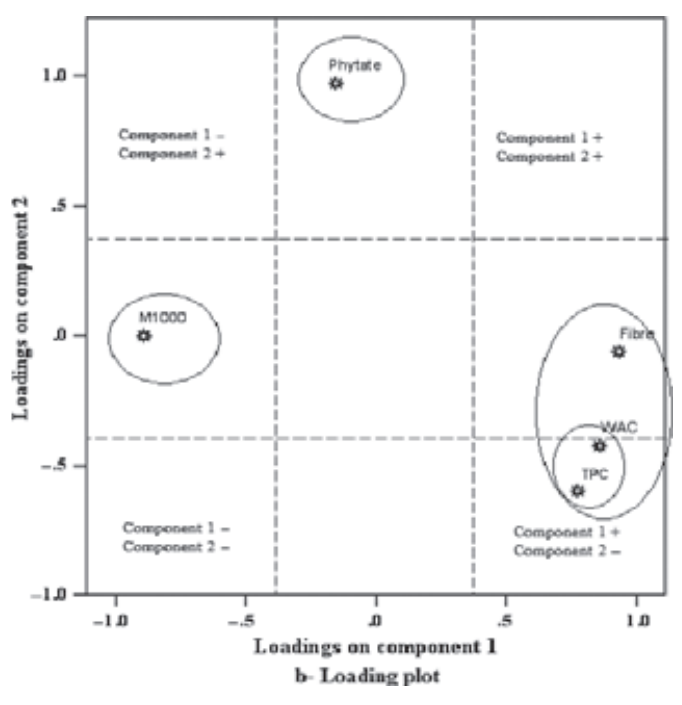

$\Delta \quad=\quad$ Pigmented landraces (Groups G1, G3, G4)

Figure 3 Cowpea landrace grouping based on nutritional and functional characteristics. 
Table 5 Pattern matrix and communalities

\begin{tabular}{llll}
\hline & \multicolumn{2}{l}{ Principal components } & \\
\cline { 2 - 3 } Variables & Component 1 & Component 2 & Communalities \\
\hline Fibre & $+0.96^{*}$ & +0.13 & 0.89 \\
1000Sw & $-0.93^{*}$ & -0.19 & 0.83 \\
WAC & $+0.81^{*}$ & -0.26 & 0.80 \\
Phenolics & $+0.68^{*}$ & -0.46 & 0.80 \\
Phytate & -0.05 & $+0.98^{*}$ & 0.95 \\
\hline
\end{tabular}

*Values greater than 0.6 .

TPC, total phenolic compounds = phenolics; WAC, water absorption capacity; $1000 \mathrm{Sw}$, thousand seeds dry weight.

Landraces of group 2, owing to their seed weight, separate themselves from the batch of landraces analysed. Landraces of group 3 showed significantly high fibre and phenolic contents as well as greater WAC. Table 2 confirms that their values for these parameters are among the highest. The landrace in group 4 separated itself from the other pigmented landraces because of its very high phytate content. The same also applies to Atchawe-tola which shows also a high phytate content within the landraces of group 1.

The integration of all compositional and functional characteristics of the studied landraces revealed that the unpigmented landraces forming $\mathrm{G} 2$ are identical to the landraces clustered as $\mathrm{C} 12$ on the basis of genetic similarity, proving that the unpigmented landraces are a very homogenous set of landraces. In contrast, the grouping of the pigmented landraces on the basis of their attributes (G1, G3 and G4) cannot be matched with any of the clusters based on genetic similarities (C11, C21 and C22). Landraces in G1, G3 and G4 are scattered in the clusters C11, C21 and C22. Consequently, pigmented landraces showed more heterogeneity regarding genetic make-up, chemical composition and functional properties. Unpigmented landraces could then easily be used interchangeably without a noticeable effect on the properties of the prepared dishes, which certainly is not the case for pigmented landraces.

\section{Conclusions}

The combined genetic and functional clustering of cowpea landraces showed that unpigmented landraces, although differently named and produced in various zones, have similar genetic, physicochemical and functional properties. These landraces may have the same ancestors. Pigmented landraces, however, were pooled in several clusters that differ with respect to genetic and functional traits. Further studies are required to evaluate the effect of the environment on functional properties of the investigated landraces.
In general, pigmented landraces were as nutritious as unpigmented ones with respect to protein and fat contents. The mineral compositions and phytate content of all the landraces were comparable except for Sokan, which showed an outstandingly high iron content $\left(104 \mathrm{mg} \mathrm{kg}^{-1}\right.$ d.w.) compared with the other landraces. Minerals and phytate contents are known to be affected by environmental conditions; a GxE evaluation may help to identify which landrace to cultivate at which location, for the best result.

The analysed landraces revealed different functionalities. However, further research should target parameters such as moisture content, particle size, etc., for a more precise determination of the suitability of a landrace to produce Atassi, Ata and Abobo. Besides, consumers need to be consulted to evaluate the acceptability of the cowpea dishes made from these landraces. This acceptability study is a key step in the selection of the best landraces for each type of food.

\section{Acknowledgments}

This research formed part of a project named TELFUN Tailoring food sciences to Endogenous patterns of Local Food supply for Future Nutrition that was financed by the North-South Interdisciplinary Research and Education Fund (INREF) of Wageningen University.

Financial support for this research was provided by the Netherlands Fellowship Programmes (Grant CF5732/2009) and the International Foundation for Science (Grant E4487-1).

We are thankful to Kwadwo Adofo, Fien Meijer and Koen Pelgrom for their contribution to DNA extraction and AFLP analysis.

\section{References}

Abu, J.O., Muller, K., Duodu, K.G. \& Minnaar, A. (2006). Gamma irradiation of cowpea (Vigna unguiculata L. Walp.) flours and pastes: effects on functional, thermal and molecular properties of isolated proteins. Food Chemistry, 95, 138-147.

Agbicodo, E.M. (2009). Genetic Analysis of Abiotic Resistance in Cowpea (Vigna unguiculata L. Walp). Plant Research International. Wageningen: Wageningen University.

Almekinders, C.J.M., Louwaars, N.P. \& de Bruijn, G.H. (1994). Local seed systems and their importance for an improved seed supply in developing countries. Euphytica, 78, 207-216.

AOAC (1984). Approved Methods of the Association of Official Analytical Chemists. Minesota, USA: St Paul.

Arens, P., Coops, H., Jansen, J. \& Vosman, B. (1998). Molecular genetic analysis of black poplar (Populus nigra, L.) along Dutch rivers. Molecular Ecology, 7, 11-18.

Asare, A.T., Gowda, B.S., Galyuon, I.K.A., Aboagye, L.L., Takrama, J.F. \& Timko, M.P. (2010). Assessment of the genetic diversity in cowpea (Vigna unguiculata L. Walp.) germplasm from Ghana using simple sequence repeat markers. Plant Genetic Resources: Characterization and Utilisation, 2, 142-150. 
Avola, G., Gresta, F. \& Abbate, V. (2009). Diversity examination based on physical, technological and chemical traits in a locally grown landrace of faba bean (Vicia faba L. var. major). International Journal of Food Science and Technology, 44, 2568-2576.

Ba, F.S., Pasquet, R.S. \& Gepts, P. (2004). Genetic diversity in cowpea [Vigna unguiculata L. Walp.] as revealed by RAPD markers. Genetic Resources and Crop Evolution, 51, 539-550.

Bentsink, L., Yuan, K., Koornneef, M. \& Vreugdenhil, D. (2003). The genetics of phytate and phosphate accumulation in seeds and leaves of Arabidopsis thaliana, using natural variation. Theoretical and Applied Genetics, 106, 1234-1243.

Caldas, G.V. \& Blair, M.W. (2009). Inheritance of seed condensed tannins and their relationship with seed-coat color and pattern genes in common bean (Phaseolus vulgaris L.). Theoretical and Applied Genetics, 119, 131-142.

Camacho, C., Maxted, N., Scholten, M. \& Ford-Lloyd, B. (2006). Defining and identifying crop landraces. Plant Genetic Resources, 3, 373-384.

Chinma, C.E., Alemede, I.C. \& Emelife, I.G. (2008). Physicochemical and functional properties of some Nigerian cowpea varieties. Pakistan Journal of Nutrition, 7, 186-190.

Coulibaly, S., Pasquet, R.S., Papa, R. \& Gepts, P. (2002). AFLP analysis of the phenetic organization and genetic diversity of Vigna unguiculata (L.) Walp reveals extensive gene flow between wild and domesticated types. Theoretical and Applied Genetics, 104, 358-366.

Dagbenonbakin, G., Sokpon, N., Igue, M. \& Ouinsavi, C. (2003). Aptitudes des Sols et Leur Répartition au Bénin: État des Lieux et Perspectives D'aménagement a L'horizon 2025. Etude $n^{\circ} 12$. Rapport Final. Direction de l'Aménagement du Territoire, MEHU, Republique du Benin.

Dagnelie, P. (1998). Statistique Théorique et Appliquée: Inference Statistique à une et à Deux Dimensions. Pp. 664. Bruxelles: De Boeck and Larcier s.a.

Digby, P.G.N. \& Kempton, R.A. (1987). Multivariate Analysis of Ecological Communities. London: Chapman and Hall.

Dovlo, F.E., Williams, C.E. \& Zoaka, L. (1976). Cowpeas. Home Preparation and use in West Africa. Pp. 97. Ottawa: International Development Research Centre.

Fang, J., Chao, C.-C.T., Roberts, P.A. \& Ehlers, J.D. (2007). Genetic diversity of cowpea (Vigna unguiculata L. Walp.) in four West African and USA breeding programs as determined by AFLP analysis. Genetic Resources and Crop Evolution, 54, 1197-1209.

Field, A. (2006). Discovering Statistics Using SPSS (and sex, Drugs and Rock ' $n$ ' Roll). Pp. 647-679. London: Thousand Oaks. New Delhi: SAGE Publications.

Frison, E.A., Smith, I.F., Johns, T., Cherfas, J. \& Eyzaguirre, P.B. (2006). Agricultural biodiversity, nutrition, and health: making a difference to hunger and nutrition in the developing world. Food and Nutrition Bulletin, 27, 167-179.

Ghavidel, R.A. \& Prakash, J. (2006). Effect of germination and dehulling on functional properties of legume flours. Journal of the Science Food and Agriculture, 86, 1189-1195.

Granito, M., Brito, Y. \& Torres, A. (2007). Chemical composition, antioxidant capacity and functionality of raw and processed Phaseolus lunatus. Journal of the Science Food and Agriculture, 87, 28012809.

Hung, T.V., Liu, L.H., Black, R.G. \& Trewhella, M.A. (1993). Water absorption in chickpea $(C$. arietinum) and field pea $(P$. sativum) cultivars using the Peleg model. Journal of Food Science, 58, 848-852.

Jones, C.J., Edwards, K.J., Castiglione, S., Winfield, M.O., Sala, F., van de Wiel, C., Bredemeijer, G., Vosman, B., Matthes, M., Daly, A., Brettschneider, R., Bettini, P., Buiatti, M., Maestri, E., Malcevschi, A., Marmiroli, N., Aert, R., Volckaert, G., Rueda, J., Linacero, R., Vazquez, A. \& Karp, A. (1997). Reproducibility testing of RAPD, AFLP and SSR markers in plants by a network of european laboratories. Molecular Breeding, 3, 381-390.
Jung, S., Rickert, D.A., Deak, N.A. et al. (2003). Comparison of Kjeldahl and Dumas Methods for Determining Protein Contents of Soybean Products. Journal of the American Oil Chemists' Society, 80, 1169-1173.

Kachare, D.P., Chavan, J.K. \& Kadam, S.S. (1988). Nutritional quality of some improved cultivars of cowpea. Plant Foods for Human Nutrition, 38, 155-162.

Kayode, A.P.P., Linnemann, A.R., Hounhouigan, J.D., Nout, M.J. R. \& Van Boekel, M.A.J.S. (2006). Genetic and environmental impact on iron, zinc, and phytate in food sorghum grown in Benin. Journal of Agricultural Food Chemistry, 54, 256-262.

Kerr, W.L., Ward, C.D.W., McWatters, K.H. \& Resurreccion, A.V. A. (2000). Effect of milling and particle size on functionality and physicochemical properties of cowpea flour. Cereal Chemistry, 77, 213-219.

Kitch, L.W., Boukar, O., Endondo, C. \& Murdock, L.L. (1998). Farmer acceptability criteria in breeding cowpea. Experimental Agriculture, 34, 475-486.

Longe, O.G. (1980). Carbohydrate composition of different varieties of cowpea (Vigna unguiculata). Food Chemistry, 6, 153-161.

Madode, Y.E., Houssou, P.A., Linnemann, A.R., Hounhouigan, D. J., Nout, M.J.R. \& Van Boekel, M.A.J.S. (2011). Preparation, consumption, and nutritional composition of West African cowpea dishes. Ecology of Food Nutrition, 50, 115-136.

McWatters, K.H. (1983). Compositional, physical, and sensory characteristics of Akara processed from cowpea paste and nigerian cowpea flour. Cereal Chemistry, 60, 333-336.

Morrison, I.M., Asiedu, E.A., Stuchbury, T. \& Powell, A.A. (1995). Determination of lignin and tannin contents of cowpea seed coats. Annals of Botany, 76, 287-290.

Ng, N.Q. \& Marechal, R. (1985). Cowpea taxonomy, origin and germplam. In: Cowpea Research, Production and Utilization (edited by S.R. Singh \& K.O. Rachie). Pp. 11-21. New York: John Wiley and Sons.

Nout, M.J.R. (1996). Suitability of high-yielding cowpea cultivars for koose, a traditional fried paste of Ghana. Tropical Science, 36, 229-236.

Oluwatosin, O.B. (1997). Genetic and environmental variation for seed yield, protein, lipid and amino acid composition in cowpea (Vigna unguiculata L. Walp.). Journal of the Science of Food and Agriculture, 74, 107-116.

Oluwatosin, O.B. (1998). Genetic and environmental variability in starch, fatty acids and mineral nutrients composition in cowpea (Vigna unguiculata L. Walp.) Journal of the Science of Food and Agriculture, 78, 1-11.

Oluwatosin, O.B. (1999). Genotype x environment influence on cowpea (Vigna unguiculata L. Walp.) antinutritional factors: 1 - Trypsin inhibitors, tannins, phytic acid and haemagglutinin. Journal of the Science of Food and Agriculture, 79, 265-272.

Padulosi, S. \& Ng, N.Q. (1997). Origin, taxonomy and morphology of Vigna unguiculata (L.) Walp. In: Advances in Cowpea Research (edited by B.B. Singh, D.R. Raj Mohan, K.E. Dashiell \& L.E.N. Jackai). Pp. 1-12. Ibadan, Nigeria: IITA and JIRCAS.

Pasquet, R.S. (1999). Genetic relationships among subspecies of Vigna unguiculata (L.) Walp based on allozyme variation. Theoritical and Applied Genetics, 98, 1104-1119.

Patane, C. (2006). Variation and relationships among some nutritional traits in Sicilian genotypes of chickpea (Cicer arietinum L.). Journal of Food Quality, 29, 282-293.

Patterson, S.P., Phillips, R.D., McWatters, K.H., Hung, Y.C. \& Chinnan, M.S. (2004). Fat reduction affects quality of akara (fried cowpea paste). International Journal of Food Science and Technology, 39, 681-689.

Quaye, W., Frempong, G., Jongerden, J. \& Ruivenkamp, G. (2009). Exploring possibilities to enhance food sovereignty within the cowpea production-consumption network in Northern Ghana. Journal of Human Ecology, 28, 83-92. 
Quaye, W., Adofo, K., Buckman, E.S., Frempong, G., Jongerden, J. \& Ruivenkamp, G. (2011). A socio-economic assessment of cowpea diversity on the Ghanaian market: implications for breeding. International Journal of Consumer Studies, 35, 679-687.

Rohlf, F.J. (2000). NTSYS - PC : Numerical Taxonomy and Multivariate Analysis System, Version 2.1. User guide. 38p. New York: Applied Biostatistics Inc.

Sathe, S.K. (2002). Dry bean protein functionality. Critical Reviews of Biotechnology, 22, 175-223.

Singh, B.B., Chambliss, O.L. \& Sharma, B. (1997). Recent advances in cowpea breeding. In: Advances in Cowpea Research (edited by B. B. Singh, D.R. Mohan Raj, K.E. Dashiell \& L.E.N. Jackai). Pp. 30-49. Ibadan, Nigeria: IITA and JIRCAS.

Singleton, V.L. \& Rossi, J.A. Jr (1965). Colorimetry of total phenolic compounds with phosphomolybdic phosphotungstic acid reagents. American Journal of Enology and Viticulture, 16, 144-158.

Temminghof, E. (1997). Soil and Plant Analysis. Part 3. Plant Analysis Procedures. Wageningen: Wageningen University Environmental Sciences.

Timko, M.P. \& Singh, B.B. (2008). Cowpea, a multifunctional legume. In: Genomics of Tropical Plants, Vol. 1 (edited by P.H. Moore \& R. Ming). Pp. 227-258. New York: Springer.
Vaillancourt, R.E. \& Weeden, N.F. (1992). Chloroplast DNA polymorphism suggests Nigerian center of domestication for the Cowpea, Vigna unguiculata (Leguminosae). American Journal of Botany, 79, 1194-1199.

Vos, P., Hogers, R., Bleeker, M., Reijans, M., van de Lee, T., Hornes, M., Frijters, A., Pot, J., Peleman, J., Kuiper, M. \& Zabeau, M. (1995). AFLP: a new technique for DNA fingerprinting. Nucleic Acids Research, 23, 4407-4414.

Vosman, B., Visser, D., van der Voort, J.R., Smulders, M.J.M. \& van Eeuwijk, F. (2004). The establishment of 'essential derivation' among rose varieties, using AFLP. Theoretical and Applied Genetics, 109, 1718-1725.

Williams, P.C., Nakoul, H. \& Singh, K.B. (1983). Relationship between cooking time and some physical characteristics in chickpeas (Cicer arietinum L.). Journal of the Science of Food and Agriculture, 34, 492-496.

Zannou, A., Kossou, D.K., Ahanchede, A. et al. (2008). Genetic variability of cultivated cowpea in Benin assessed by ramdom amplified polymorphic DNA. African Journal of Biotechnology, 7, $4407-4417$. 